\title{
Os desafios da Itália na emergência do coronavírus
}

Os desafios da Itália na emergência do Coronavírus

Il sfide il Italia in emergenza di coronavirus

Los desafíos de Italia en la emergencia del coronavirus

Italy's challenges in the emergence of the Coronavirus

Les défis italiens face à l'émérgence de la Covid-19

\section{Roberto Montemerli}

\section{OpenEdition}

Journals

\section{Edição electrónica}

URL: http://journals.openedition.org/espacoeconomia/11312

DOI: 10.4000/espacoeconomia.11312

ISSN: 2317-7837

\section{Editora}

Núcleo de Pesquisa Espaço \& Economia

\section{Refêrencia eletrónica}

Roberto Montemerli, « Os desafios da Itália na emergência do coronavírus », Espaço e Economia

[Online], 17 | 2020, posto online no dia 08 abril 2020, consultado o 10 dezembro 2020. URL : http:// journals.openedition.org/espacoeconomia/11312; DOI : https://doi.org/10.4000/espacoeconomia 11312

Este documento foi criado de forma automática no dia 10 dezembro 2020

\section{(c) (i) (9)}

Espaço e Economia - Revista brasileira de geografia econômica est mise à disposition selon les termes de la licence Creative Commons Attribution - Pas d'Utilisation Commerciale - Partage dans les Mêmes Conditions 4.0 International. 


\title{
Os desafios da Itália na emergência do coronavírus
}

\author{
Os desafios da Itália na emergência do Coronavírus \\ Il sfide il Italia in emergenza di coronavirus \\ Los desafíos de Italia en la emergencia del coronavirus \\ Italy's challenges in the emergence of the Coronavirus \\ Les défis italiens face à l'émérgence de la Covid-19
}

\section{Roberto Montemerli}

Italia; pandemica; sistema sanitario pubblico; gestione delle crisi; il futuro

1 Os dois primeiros casos de contagio pelo vírus causador da COVID-19, oficialmente registrados na Itália, foram um casal de turistas chineses, confirmados em 30 de janeiro pelo Instituto Spallanzani, Instituto Nacional de Doenças Infecciosas, em Roma, onde foram hospitalizados isoladamente a partir de 29 de janeiro. Em 26 de fevereiro, eles foram declarados curados. Também em 30 de janeiro, nos outros países europeus, os casos confirmados foram: cinco na França, um na Finlândia e quatro na Alemanha, todos relacionados à China, data em que haviam, no total, 7818 casos confirmados em todo o mundo, dos quais 7.736 na China (Relatório nํㅜ 10 da OMS).

$\mathrm{O}$ ano novo havia começado com as notícias, trazidas pelos repórteres baseados no Extremo Oriente, que contavam do gigante chinês à mercê de um novo vírus, da mesma cepa da SARS de 2003. As notícias dos contágios e das medidas para combater a expansão do vírus ficavam a cada dia mais veiculadas e preocupantes. Parecia que estávamos assistindo a um filme já visto. De fato, este "novo" século estava sendo marcado por cíclicas epidemias virais que ameaçavam o mundo inteiro.

3 A epidemia da SARS (Síndrome Respiratória Aguda Grave) começou na província chinesa de Guangdong em novembro de 2002 e deixou, durante meses, o mundo com a respiração suspensa. No início de abril de 2003, a SARS começou a receber atenção da mídia oficial, depois da morte do americano James Earl Salisbury. Na Itália, a participação emotiva coletiva foi particularmente grande devido à morte no Vietnã do 
médico italiano Carlo Urbani. Ele foi o primeiro a identificar o vírus como uma nova e perigosa doença e tragicamente contagiou-se e morreu.

4 A "gripe suína" surgiu em abril de 2009, no México, causada por uma variante até então desconhecida do vírus H1N1. Foi uma pandemia concentrada no continente americano, porém teve bastante repercussões também nas mídias da Europa e da Itália, atingindo o estágio 6, o máximo dos níveis de alerta pandêmico.

Depois foi a vez da SRME ou em inglês MERS, ou seja, a Síndrome Respiratória do Médio Oriente. 0 primeiro caso relatado foi em 24 de setembro de 2012 na Arábia Saudita e desde então, não existindo uma vacina, todos os anos aparecem nos jornais manchetes com títulos alarmistas informando que a nova SARS está de volta na Europa.

6 Por último, surgiu a gripe aviária que, a partir de 28 de dezembro de 2016, atingiu a Itália. Um vírus altamente patogênico que afetou os pássaros da maior parte da Europa, entre 2016 e 2017, disseminando-se o medo de que esse novo vírus animal pudesse ser contraído por seres humanos.

7 Mas, apesar dos pesares e dos alarmes provocados, essas doenças nunca atingiram direta e intimamente o mundo ocidental. A SARS causou 774 vítimas confirmadas e está definitivamente debelada. A gripe suína causou milhares de mortes e centenas de milhares de infecções em todo o mundo. Embora o contágio fosse considerável, o risco de morte era decididamente baixo, 0,05 dos infectados, menos da metade de uma gripe comum, e atingiu principalmente a América Central. A MERS, mesmo aparecendo todos os anos na Europa, de abril de 2012 a 13 de outubro de 2015, conta um total de 1.616 casos humanos de infecção por coronavírus (Mers CoV). Pelo menos 624 mortes foram relatadas à Organização Mundial da Saúde (OMS), mas a quase totalidade nos países do oriente médio. Da gripe aviária, foram confirmados 83 surtos em aves domésticas, envolvendo os setores rural e industrial. Porém não foram registrados casos na Europa de contágio em seres humanos ${ }^{1}$.

8 Como visto, as precedentes pandemias não permitiam prever o desastre que hoje está na frente de nossos olhos. As notícias sobre o novo coronavírus, mesmo ocupando boa parte dos jornais e noticiários, não conseguiram preocupar seriamente a opinião pública. Ainda mais porque as notícias e as primeiras evidências científicas, que chegavam da China, contavam de um vírus com uma taxa de mortalidade baixa e que atingia principalmente os idosos. Nós, profanos, não entendíamos o porquê de tanto desespero. A construção às pressas de hospitais, as imagens dos médicos com macacões brancos, máscaras de últimas gerações e agasalhados como nos filmes hollywoodianos evocavam hilaridade, remetendo ao exagero e meticulosidade dos chineses. Hoje, diante da atual situação, nos certificamos o quão estávamos errados.

9 Como nos advertia Nietzsche, no prefácio do Escrito "Sobre a utilidade e a desvantagem da história para a vida", o homem não pode aprender a esquecer e depende do passado: por mais longe ou rápido que ele corra, essa corrente corre com ele? Na genética e na psicologia, identifica-se esse processo com um mecanismo, que é chamado de imprinting, ou impressão emocional, em que as experiências que mexeram com nossas emoções determinam mentalmente mudanças fisiológicas permanentes, que na vida prática se traduzem em novas crenças, novos parâmetros comportamentais e, portanto, novas atitudes em relação a uma determinada coisa ou evento futuro.

10 As experiências adquiridas nas ocasiões da SARS e da MERS, passando pela "gripe suína" e aviária, influenciaram as atitudes da população perante essa nova epidemia. $\mathrm{E}$ 
isto adquire um peso especial em épocas de populismos, quando, talvez mais do que nunca, os humores das massas determinam as escolhas e comportamentos da política. $O$ povo se torna o epicentro de comportamentos e atitudes, e se antes as issues (os problemas a serem resolvidos na escala pública) eram debatidas e determinadas pelos partidos, com o declínio das ideologias, as correntes do populismo atravessam a sociedade e se infiltram nas mídias e nos territórios da política, determinando prioridades e soluções. A Internet e as mídias sociais permitem a cada indivíduo ser informado em tempo real sobre o que acontece no mundo inteiro e lhe permitem também expressar a própria opinião. Através do processo de mass self-comminication, o sujeito se autocomunica, elaborando de forma autônoma as mensagens que veicula a um número grande de destinatários, podendo exercer pressões políticas por esse meio. A preservação do status quo passa, de um lado, pela influência da opinião pública, mas também através do processo de conformação da politica à opinião pública. Nas redes sociais, o uso das fakenews e da comunicação orientada especialmente para determinados grupos da sociedade é funcional a deixar a opinião pública mais volúvel, fragmentada e influenciável. Por outro lado, as mídias tradicionais vêm exercendo um papel mais sensacionalista, brincando com as emoções das pessoas e popularizando a política na tentativa de torná-la conforme aos gostos e modas correntes. Isto é, o populismo propõe soluções simples para problemas complexos. As mesmas soluções que se ouvem nas conversas de mesas de bar.

11 A opinião pública historicamente nasce com o estado liberal de direito, favorecendo e influenciando o seu nascimento e desenvolvimento, com as prerrogativas filosóficas apresentadas nos escritos de Locke e de Kant. Locke teorizava a existência de uma "lei da opinião e reputação" que permite julgar as ações da política, em suma, uma moral necessariamente distinta da política. Kant destacava a exigência do uso público da razão iluminista como livre porta-voz das demandas do povo, que alcança e julga publicamente os políticos e suas ações, para influenciar sua conduta de governo.

$12 \mathrm{Na}$ modernidade, como bem analisaram os marxistas, sobretudo os da escola de Frankfurt, a opinião pública foi totalmente influenciada pela indústria cultural, pelo mercado editorial, pelos novos meios de difusão de ideias e opiniões destinadas ao público, na lógica de garantir o consumo e o lucro, a vantagem daqueles que detêm o poder político e social, e para sua constante legitimação. Na pós-modernidade a opinião pública é persuadida, uma verdade seduzida com a ilusão de ser independente e autoproduzida através da mídia social. Na verdade, a opinião pública se torna uma bandeira que muda de direção continuamente, ao vento de um spot ou de um story de facebook ou instagram. Na Itália, a prova disso é a total volubilidade dos eleitores que, nas eleições dos últimos anos, votaram em massa antes para partidos de esquerda, depois para partidos populistas e, nas últimas eleições europeias, para partidos de extrema direita. Ou seja, os eleitores escolheram sempre quem soube falar para eles o que queriam e foram preparados e dispostos a ouvir.

13 O sentimento de alteridade perante o corona vírus gerou subestimação e minimização do problema, e foi nesse cenário que a Itália foi chamada a lidar com essa nova doença. Já no final de janeiro, o governo teve que assumir algumas medidas que, em retrospectiva e considerando-se a pouca ênfase que foi dada, parecem terem sido meras formalidades ditadas pelas decisões tomadas da OMS.

o primeiro ato do governo italiano de enfrentamento ao coronavírus foi uma circular do Ministério da Saúde emitida no dia 21 de janeiro, com o assunto: "Polmonite da nuovo 
coronavírus (2019 - nCoV) in Cina", ou seja, Nova pneumonia por coronavírus (2019 $\mathrm{nCoV}$ ) na China. A circular inicia oficializando a notícia de que a Comissão Municipal de Saúde de Wuhan, na China, informou à Organização Mundial de Saúde (OMS), no dia 31 de dezembro de 2019, sobre casos de pneumonia de etiologia desconhecida limitados à cidade de Wuhan, na província chinesa de Hubei. A maioria dos casos tinha uma conexão epidemiológica com o mercado de Huanan Seafood, no sul da China, um mercado atacadista de frutos do mar e animais vivos. A circular continua destacando os sintomas mais comuns da doença e alertando que uma forma inicialmente leve pode progredir para uma forma grave, especialmente em pessoas com condições clínicas crônicas preexistentes, como hipertensão e outros problemas cardiovasculares, diabetes, doença hepática e outras doenças respiratórias, e que até as pessoas mais velhas podiam ser mais suscetíveis às formas graves. 0 Ministério da Saúde informava também que, desde 9 de janeiro de 2020, o Centro de Prevenção e Controle de Doenças chinês (CDC) havia comunicado que um novo coronavírus havia sido identificado, sendo denominado 2019-nCoV e tornada pública sua sequência genômica. E que, em 21 de janeiro de 2020, foram registrados casos com histórico de viagens entre Wuhan e outras áreas da China, como Pequim, Guangdong e Xangai. Tailândia, Japão e Coréia do Sul também tinham casos relatados. A circular concluía participando que as autoridades chinesas e a OMS haviam confirmado que a transmissão foi demonstrada por pessoa a pessoa, e, sobretudo, informaram que houve casos entre profissionais de saúde. Portanto recomendava que, por motivos de precaução, os profissionais de saúde, além de tomar medidas de biossegurança normais, adotassem precauções para impedir a transmissão por via aérea e contato. Em particular, usar máscara facial e proteção facial, vestimenta impermeável com mangas compridas e luvas. Também apontava que as máscaras devem ser do tipo FFP2.

Essa primeira circular do Ministério da Saúde, que analisei no paragrafo acima, revela como quase todas as informações sobre a epidemia eram de domínio público. De fato, a China, diversamente de como aconteceu com a SARS, que a expôs a ser alvo de muitas críticas internacionais, não negou a existência do vírus e foi o mais aberta e colaborativa possível com a OMS e a comunidade científica internacional.

Assim, diante das informações sobre os riscos de disseminação do novo vírus, na Itália, em 22 de janeiro, foi criada uma task force (força-tarefa) do coronavírus, com a tarefa de coordenar 24 horas por dia as ações a serem tomadas para evitar a propagação da epidemia no país. A task force se reuniu diariamente para coordenar e implementar, em conexão contínua com as instituições internacionais competentes, as ações de controle a serem tomadas para limitar a propagação do vírus e verificar o cumprimento das recomendações da OMS e do Centro Europeu de Prevenção e Controle de Doenças (ECDC). Em particular, alertar as estruturas de saúde responsáveis por lidar com a situação; ativar controles nos aeroportos e verificar o pleno funcionamento dos procedimentos iniciados; fornecer as indicações operacionais por meio de circulares às instituições, órgãos e organizações profissionais interessadas; gerenciar casos confirmados no país em colaboração com as Regiões e os hospitais. Além disso, foi implementado um serviço público de atendimento telefônico ao número 1500, ativo 24 horas por dia, em que agentes de saúde e mediadores culturais especialmente treinados forneceriam respostas às perguntas dos cidadãos. Por fim, foi ampliado o controle nos aeroportos, sobretudo dos passageiros provenientes da China, e neles determinada a aposição de cartazes informativos com dicas de prevenção. 
17 Em 31 de janeiro, o Governo da Itália, com um Decreto do Presidente do Conselho de Ministros, dispôs o estado de emergência de saúde. A decisão foi tomada só após a OMS declarar a emergência de saúde pública de interesse internacional.

Naquela ocasião, o Ministro da Saúde, Roberto Speranza, em declarações oficiais, disse:

queremos transmitir uma mensagem de absoluta serenidade. O Serviço Nacional de Saúde é muito forte, optamos desde o início por ter um nível de atenção mais alto da Europa. No momento, somos o único país que interrompeu as conexões com a China. A OMS reconheceu publicamente que somos os que têm o mais alto nível de vigilância e salvaguarda das pessoas.

O primeiro caso de transmissão secundária registrado na Itália ocorreu em Codogno, município a sudoeste de Milão na província de Lodi, na Lombardia, região norte da Itália, no dia 21 de fevereiro. 54 minutos depois da meia-noite, a National Associated Press Agency (ANSA), primeira agência de informações multimídia da Itália, lançou a notícia: "Coronavírus, uma pessoa infectada na Lombardia". De manhã, o secretário do welfare e saúde da Região da Lombardia, Giulio Gallera, informou em uma entrevista coletiva que um italiano de 38 anos de idade, que nunca esteve na China, deu positivo e havia sido internado no hospital de Codogno. A situação mudou completamente em relação ao dia anterior porque, naquele instante, tivemos a certeza de que o vírus estava circulando na Itália. Esse caso foi denominado pela mídia "paciente 1". A reação do campo político e da mídia foi pronta e às três horas da tarde, ao vivo na TV, mostrava-se que Codogno estava isolada do resto do mundo, conforme a ordem do representante local do Governo central.

20 A história desse contágio teve um grande destaque na imprensa e na opinião pública italiana, iniciando-se, a partir de então, uma verdadeira caçada ao "paciente 0". As mídias acompanharam as instituições nessa busca, tentando reconstruir os últimos dias do gerente da Unilever de 38 anos: partindo da corrida em Sant'Angelo Lodigiano, ao curso feito na Cruz Vermelha, à pelada com os amigos e até à sua participação no carnaval da cidade. No mesmo dia 21 , poucas horas depois, sugiram as primeiras mortes na Itália: uma mulher em sua casa em Casalpusterlengo, perto de Codogno, mãe de um amigo do paciente 1, e um homem idoso (hospitalizado com sua esposa) porém em outra região, no município de Vò Euganeo, no Veneto, longe do surto de Codogno.

21 Em pouquíssimas horas, o número de pessoas infectadas na Itália subiu para 19 (das quais 14 na Lombardia e 5 no Veneto) e a Itália se tornou o país com mais casos na Europa. Seguiram-se horas animadas de transmissões ao vivo e de entrevistas coletivas e pronunciamentos. As Portarias do Ministério da Saúde e das Regiões da Lombardia e do Veneto decretaram duas "zonas vermelhas", ou seja, áreas de contenção do vírus onde há risco máximo de contágio e que devem permanecer isoladas do resto do mundo, com todas as atividades fechadas. Cerca de 50 mil pessoas e dez municípios, onde foram detectados os primeiros casos, foram isolados. O ministro Speranza pediu para todos os italianos ficarem em casa, enquanto todos aqueles que tiveram contato direto com as 19 pessoas infectadas, permaneceriam em isolamento obrigatório.

22 Naquele exato momento, a subestimação do perigo virou medo. A opinião pública, frente a esse trauma, perdeu a veleidade de ser autônoma e independente, ficando a mercê da mídia e da política.

23 Matteo Salvini, o líder da extrema direita e secretário da Lega, o partido que lidera as intenções de votos com mais de $30 \%$ de aprovação, publicou um post ordenando que o 
governo fechasse tudo: "Chiudere! Blindare! Proteggere! Controllare! Bloccare!" ("Fechar! Blindar! Proteger! Controlar! Bloquear!").

No dia seguinte, 22 de fevereiro, o número de infectados chegava a 76 e no dia 23 de fevereiro mais um decreto do Presidente do Conselho de Ministros, Giuseppe Conte, em conjunto com o Ministro da Saúde, Roberto Speranza, fechou as escolas de todas as ordens e graus em seis regiões do norte da Itália.

No entanto, as mídias continuaram com uma enorme cobertura. $90 \%$ dos jornais eram dedicados ao coronavírus, as entrevistas coletivas dos presidentes das regiões e da task force, representadas pelo chefe do Departamento de Proteção Civil, Angelo Borelli, se tornaram um compromisso fixo e esperado para todos os italianos, para conhecer a evolução da epidemia.

Os italianos tentaram exorcizar esse pânico inicial organizando encontros com skype e zoom ou se programando para saírem todos ao mesmo tempo nas janelas e varandas para cantar, ou simplesmente para fazer barulho. Cantos e panelaços que, em retrospectiva, dissonam com os acontecimentos macabros que estavam envolvendo muitas pessoas.

Após uma semana de isolamento social, os humores dos italianos eram bastante controversos. O espírito de sacrifício e o medo já tinham se esgotado e a epidemia, mesmo que os números aos olhos dos mais experientes fossem preocupantes, para o italiano médio não era uma presença tangível no dia a dia. Nas últimas 24 horas do dia 27 de fevereiro haviam sido registrados 107 contágios e quase todos limitados às áreas já interessadas. Esses são os dados divididos por regiões e comunicados na entrevista coletiva às 18:00 do dia 27 de fevereiro, pelo chefe do Departamento de Proteção Civil2:

Lombardia 403

Veneto:111

Emilia Romagna: 97

Liguria: 19

Sicilia: 4

Campania: 3

Lazio: 3 (os 2 turistas chineses e um pesquisador italiano resgatado da Wuhan - todos curados)

Marche: 3

Piemonte: 2

Toscana: 2

Abruzzo: 1

Puglia: 1

Provincia Autonoma di Bolzano: 1

2 Assim, começam a se levantar os gritos bipartisan (bipartidários) contra o alarmismo injustificado. O prefeito de Milão Giuseppe Sala, eleito com uma coalizão de centroesquerda, pede ao governo que reabra os museus e que reabra os bares e locais públicos, após as 18 horas, fechados por uma portaria da Região da Lombardia, governada por uma coalização de centro-direita. Sala tirou fotos vestindo uma camiseta 
com o hashtag \#milanononsiferma (\#milaonaopara), e tomando aperitivo. No mesmo dia, o secretário do Partido Democrata, Nicola Zingaretti, foi ao "Navigli", bairro da movida de Milão, para tomar um aperitivo simbólico com os jovens do partido. Nove dias depois, ele anunciaria que estava positivo para o coronavírus. Matteo Salvini pediu um encontro com o presidente da República, Sergio Mattarella, com o objetivo de pedir para "reabrir tudo e fazer recomeçar a Itália", e intimou o governo para "reabrir tudo que pode ser reaberto. Reabra para relançar fábricas, lojas, museus, galerias, academias, discotecas, bares, restaurantes, shopping centers! ". No dia seguinte, Salvini continuou postando nas suas páginas nas mídias sociais apelos para reabrir tudo: "Abrir, abrir, abrir! Volte para a produção, compre, volte a sorrir". Naturalmente, as Associações Empresariais, Comerciais e Industriais foram claramente a favor da reabertura. Tudo isso enquanto os mortos e contágios aumentavam e a OMS eleva, no dia 28 de fevereiro, o índice de ameaça internacional do coronavírus para muito alta.

As declarações dos políticos e dos tantos opinionista e jornalistas ligados à direita extrema ou ao pensamento neoliberal, daqueles dias, foram criminosas. Se de um lado, como sempre, foram funcionais a favorecer as classes sociais de referência, de outro, agradaram a opinião pública que mais uma vez ouviu o que queria ouvir e, em cumplicidade com a primavera, que mostrou os seus primeiros traços, os italianos invadiram qualquer espaço público que não estava fechado em virtude dos decretos. Os virologistas calculam que a curva epidêmica chegou a seu ápice justamente em função daqueles dias e que o pico de óbitos, que se verificou no final de março, é compatível com as infecções contraídas naqueles dias, calculando-se o tempo de incubação e curso da doença.

Do outro lado, os dados e os cientistas pediam às instituições medidas ainda mais radicas. E só no dia 4 de março o governo se dispôs a suspender as atividades de todas as escolas de ordens e grau da Itália inteira. No dia 8 de março toda a Região Lombardia e 14 províncias do norte eram declaradas "zona vermelha". Academias, piscinas, cinemas e teatros permaneceriam fechados e bares e restaurantes fechariam às 18:00 horas. Funerais e casamentos foram proibidos, assim como visitas nos presídios. De acordo com a CNN, círculos próximos ao governo teriam deixado vazar informações confidenciais, relativas às medidas deliberadas pelo Conselho de Ministros na noite antecedente à assinatura do Decreto. Isso provocou a fuga de milhares de pessoas para o sul. Muitas pessoas que residem no norte da Itália são oriundas das regiões do sul e, como muito lugares de trabalho estavam fechados, voltaram para as casas de seus familiares. Esse ato de incivilidade foi devastador, pois causou a propagação do vírus aos próprios entes, muitos dos quais acabaram morrendo.

As fugas fizeram com que, no dia seguinte, um novo pronunciamento do premier anunciasse a adoção de um novo decreto-lei que fazia da Itália inteira uma "zona vermelha", ou seja, as medidas de contenção foram estendidas ao inteiro território nacional. Foi a portaria denominada "Eu fico em casa", que dispôs sobre a proibição de aglomerações e a possibilidade de se movimentar apenas por trabalho, saúde ou necessidades, como fazer as compras de bens de primeira necessidade. Para sair de casa, passou a ser necessário levar consigo uma declaração sobre o motivo da saída (autocertificação). o novo decreto prorrogou o fechamento de escolas e de todas as atividades esportivas, inclusive caminhadas e corridas, mesmo em lugares afastados da cidade. Mas no dia 9 de março a Itália se tornava o segundo país do mundo, depois da China, a sofrer mortes relacionadas ao coronavírus. Nas cadeias, registravam-se motins 
causados pela disposição que vetava as visitas. Salvini, no mesmo dia, mudou novamente de opinião e twittou: "chega! fechar tudo!".

No dia 10 de março, os profissionais da saúde lançaram o alerta de que os contágios entre eles haviam aumentado preocupantemente. 0 protocolo em uso nos hospitais não parecia garantir a incolumidade dos trabalhadores e eles advertiam também que os assintomáticos não eram revelados, mesmo se entrassem em contato com os infectados. Naquela data, o número de contagiados subiu para 10.149 casos, ultrapassando a cota de 10 mil contágios. O sistema de saúde pública da Lombardia entrou em colapso. As UTI estavam cheias e o Centro Remoto de Operações de Socorro Sanitário (Cross), ativado pelo Departamento de Proteção Civil, coordenava as transferências de pacientes em terapia intensiva da região da Lombardia para outras regiões menos atingidas pelo coronavírus, por meio de ambulâncias médicas das associações voluntárias e da proteção civil e de helicópteros e veículos aéreos da Força Aérea.

o Decreto do Primeiro-Ministro, de 22 de março de 2020, determinou que, em todo o território nacional, fechassem as atividades comerciais e de produção industrial, com exceção das essenciais como, por exemplo, as produtoras e distribuidoras de energia e artigos alimentares (pesca e agricultura). Além disso, proibiu-se o deslocamento, em meios de transporte público ou privado, para municípios diferentes daqueles em que as pessoas se encontravam no momento da medida, exceto para retornar para a prefeitura de residência ou para comprovadas necessidades ligadas ao trabalho, à urgência absoluta ou por razões de saúde.

Desde então, o governo e a Itália inteira estão na janela aguardando ansiosamente a queda do número de contágios e com a preocupação de que o nosso sistema de saúde pública possa se segurar até que a curva epidêmica abaixe. Porém, durante muitos dias, pelo contrário, as mortes e os contágios mantiveram-se aumentados.

49 Vários especialistas, virologistas, médicos e técnicos ministeriais já admitiram algumas falhas na gestão da crise. Em particular, é opinião comum que, como fizeram na China, teria sido necessário criar hospitais só para os pacientes infectados por COVID-19. Os hospitais podem ter sido um veículo importante para espalhar o vírus. Ilaria Capua, virologista e ex-política, supõe que o "modelo de saúde" da Lombardia não apenas espalhou o vírus, mas também o multiplicou através dos condutos de ventilação contaminados dos antigos hospitais públicos, cujas estruturas não foram adequadamente renovadas, enquanto os recursos financeiros eram destinados à saúde privada.

É importante esclarecer, neste caso, que a Reforma Constitucional de 2001 determinou que a gestão da saúde pública fosse competência exclusiva das Regiões. Ao Estado caberia só definir, anualmente, quais são os Níveis Essenciais de Assistência (Livelli Essenziali di Assistenza - LEA). A Região da Lombardia, por quase 20 anos, desde 1995 até 2013, foi administrada pelo mesmo Governador, Roberto Formigoni, membro da "Comunione e Liberazione", um movimento católico laico integralista, e apoiado por uma coalizão de centro-direita. Quando em 2001 a Região da Lombardia foi chamada a gerir a saúde pública, a administração Formigoni cogitou um modelo de integração entre público e privado. Não é pecado pensar que esse sistema foi pensado para favorecer a saúde privada que, em 2001, na Itália, estava em sua quase totalidade nas mãos de movimentos ou fundações de inspiração católica. Com esse sistema, os pacientes podem escolher se beneficiar de prestações e serviços em estruturas públicas ou particulares. Os serviços prestados pela saúde privada são então reembolsados pela Região. Roberto 
Formigoni, em 19 de setembro de 2018, foi condenado a 7 anos e 6 meses de prisão, por corrupção, justamente por ilícitos ligados à saúde publica.

51 Massimo Galli, especialista em doenças infecciosas e chefe do departamento de infectologia do hospital Luigi Sacco, de Milão, confirma o que o premier Giuseppe Conte disse quando, sem culpar médicos e enfermeiros, percebeu que algo não havia funcionado no hospital de Codogno e, ele acrescenta, também no hospital de Alzano Lombardo, na província de Bergamo. O professor Galli aponta que os hospitais ampliaram a doença, sobretudo porque não investigaram muitos pacientes com pneumonias suspeitas, pensando que o vírus pudesse ser trazido só por alguém que viesse da China e, enquanto isso, o vírus circulou livre por quatro semanas antes de ser notado. Os jogos de futebol que inicialmente não foram suspensos, a possível mutação do vírus e o absurdo dos políticos de subestimar o problema, bebendo aperitivos para ilustrar sua segurança, fizeram o resto, junto com o Governo da Região, mais sensível aos industriais que aos virologistas.

Porém as maiores falhas, sempre da política, não foram durante a gestão da crise, e sim pela falta de prevenção. Bill Gates, em 2015, no seu monólogo para TED, havia nos avisado que para o próximo surto não estaríamos prontos. Ele afirmava que o que vai matar mais de 10 milhões de pessoas nas próximas décadas vai ser um vírus altamente contagioso. Isso porque não existe um sistema internacional para parar uma epidemia. o fracasso global aconteceu na época do ebola, e o balaço de mortos não foi tão grande porque o ebola é um vírus que não se espalha através do ar e, no momento em que estão contagiosas, as pessoas infectadas, em sua maioria, estão tão doentes que ficam acamadas. Ele advertia que, caso se espalhasse um vírus cujo contágio se dê no momento em que as pessoas ainda se sentem bem, seria um desastre. As palavras de Bill Gates, de 5 anos atrás, parecem ser proféticas, mas na realidade só repetem o que todos os virologistas diziam desde 2003, ou seja, desde a epidemia da SARS. Muitos estudos apontam que, em 2050, a primeira causa de morte serão as epidemias provocadas por vírus e as bactérias super-resistentes.

Estudando-se o genoma completo e sobretudo as sua mutações, foi possível definir a data certa do início da epidemia, quando o vírus do animal passou a infectar o ser humano. Os epidemiologistas identificam como data de começo da pandemia o meado de novembro de 2019. Data confirmada também por uma investigação do jornal de Hong Kong "South China Morning Post". Baseado em dados oficiais, o jornal escreveu que o primeiro caso conhecido de infeção pelo COVID-19 foi no dia 17 de novembro, na província chinesa de Hubei, e se tratou de um homem de 55 anos. Estudos do Politécnico de Zurique, conduzidos diretamente na região de Wuhan, calcularam a porcentagem de difusão do vírus que vai de 2 até 3,5. Percentual muito alto, comparado com o da normal gripe sazonal, cuja taxa de propagação é de $1,3 \%$. Wuhan foi colocada em quarentena só no dia 23 de janeiro; portanto, o vírus teve um bom tempo para se propagar na China e, muito provável também, para fora, sendo Wuhan um importante centro econômico, comercial, financeiro e tecnológico. Além de logístico, com dezenas de ferrovias, estradas e vias expressas e um aeroporto com voos diretos para quase todas as capitais do mundo.

o COVID-19 é um vírus com uma incubação totalmente assintomática, que pode chegar até 14 dias, e se calcula que $80 \%$ dos contagiados não apresentam sintomas relevantes e ficam conduzindo uma vida normal. Esse novo coronavírus apresenta todas as caraterísticas mais temidas pelos epidemiologistas, mas a nota mais dramática é o 
percentual de difusão. O vírus se expande muito rapidamente e uns $10 \%$ dos doentes desenvolvem pneumonia viral intersticial bilateral, necessitando de intubação com respiradores artificiais que permitam a ventilação mecânica. Se esses $10 \%$ são mais que as vagas nas UTI disponíveis o são superiores aos números de respiradores, o sistema de saúde colapsa. Assim, parte importante dos doentes não vai morrer pela doença em si, que seria teoricamente curável, mas por falta de equipamentos. Sem dizer que a falta de vagas nas UTIs compromete também pacientes atingidos por outras patologias, como infartos, derrames cerebrais, acidentes graves etc...

Após a SARS, a OMS recomendou que todos os países desenvolvessem um plano de prevenção e resposta a uma pandemia e o atualizassem constantemente. A Itália cumpriu a obrigação de redigir o plano, porém ficou só no papel. Portanto, são 17 anos que os dirigentes da saúde e os políticos sabem e foram advertidos da periculosidade e da altíssima probabilidade de que um vírus parecido com a SARS voltasse. Em vista disso, deveriam ter estocado máscaras e outros Equipamentos de Proteção Individual (EPI), testes para diagnósticos rápidos e confiáveis e respiradores pulmonares; deveriam ter aumentado as vagas nas UTI e investido em capital humano. Pelo contrário, nos últimos anos o estado e as regiões continuaram operando cortes no orçamento para a saúde e reduzindo o número de leitos hospitalares.

Essa falta de estruturas e de adequadas proteções, listadas na própria primeira circular do Ministro da Saúde Pública, de 21 de janeiro, acima analisada, fizeram com que, segundo dados divulgados pelo Instituto Superior de Saúde (ISS), na Itália desde o início da epidemia, $10 \%$ dos contagiados fossem profissionais de saúde. No dia 27 de março, 414 profissionais de saúde estavam infectados e 51 mortos, enquanto o número total de pacientes era de 62.013. Nessa guerra, perdemos a linha de frente dos que combatiam contra o vírus, por não saber orientá-los e lhes dar as devidas condições de atuação. Os sindicados contam que $1 / 4$ dos profissionais nos hospitais mais atingidos estão doentes com sintomas, mas sabemos que a doença é sintomática só em $20 \%$ dos infetados. Presumivelmente, portanto, é correto pensar que a quase totalidade dos profissionais de saúde em atuação nesses hospitais tenha contraído o vírus. $O$ fato de que as autoridades, mesmo se solicitadas por alguns políticos e sindicados de categoria, não dispusessem testes de massa para todos os profissionais, parece comprovar essa hipótese.

57 As falhas e sombras sobre a epidemia de COVID-19 na Itália não terminam aqui. Quase todos os números oficiais não seriam representativos da realidade. Como relatam inúmeros profissionais de saúde de hospitais e médicos genéricos - esses últimos aqui na Itália atendem diretamente cada família (médico de família) -, a práxis seria a descrita a seguir. Os infectados se sentem mal, a febre aumenta por 2-3 dias e o doente deve ficar em contato com o médico de família, que monitora a situação por telefone; nessa fase, é proibido ir para o hospital e ninguém vai sujeitar o paciente ao teste diagnóstico para saber se a febre decorre do coronavírus. 0 paciente, passados os primeiros dois dias, ou se recupera e fica melhor ou piora fortemente e, após 5 a 6 dias a crise respiratória, pode apresentar um quadro fatal, isto é, morrer em menos de uma hora porque a troca entre oxigênio e dióxido de carbono nos pulmões é insuficiente, assim como o fluxo de oxigênio para o cérebro, provocando a morte no próprio leito. Se o paciente sobreviver, será levado por uma ambulância para a triagem do hospital, onde receberá oxigênio e, só então, vai ser sujeitado ao teste diagnóstico para apurar se realmente tem COVID-19. Em suma, se o paciente morrer em casa a morte vai ser 
declarada por ataque cardíaco ou pneumonia e não será atribuída ao coronavírus. Essa não é só uma falha nas contas dos mortos por COVID-19. O outro problema é que o defunto, não sendo declarado morto por COVID-19, pode ser enterrado e não cremado, e os parentes e as outras pessoas que tiveram contato com ele não têm obrigação de ser colocadas em quarentena.

Os dados de mortos registrados pelas prefeituras sufragam os contos e as dúvidas dos médicos. 0 número de mortos, desde que começou do surto, é bem maior que a média do mesmo período dos anos anteriores. Bergamo é a cidade italiana mais afetada pela epidemia de coronavírus; os dados, divulgados o dia 25 de março contabilizavam 7.072 infectados. 0 prefeito da cidade, Giorgio Gori, no mesmo dia, twittou que, desde o dia 1 até 24 de março, 446 moradores da cidade morreram, 348 mais do que a média registrada nos últimos anos, que é de 98 mortos. As mortes oficiais devidas à COVID-19 no período foram 136. Portanto, tirando os mortos por COVID-19 oficialmente reconhecidos, foram verificados 212 mortos acima da média. E continua dizendo que, de acordo com os estudos, calculando uma mortalidade de 1,5-2\% dos afetados, haveriam na cidade por volta de 17 a 23 mil infectados, três vezes mais do que o dado oficial. 0 Dr. Galli, do hospital L. Sacco, de Milão, diz que a porcentagem de mortes em comparação com o número de pacientes afetados por COVID-19 internados em seu departamento está exatamente igual à porcentagem que as autoridades dão entre o número de infecções e de mortos. Em suma, é provável, acreditar que o número oficial de pessoas infectadas corresponda apenas ao número de pacientes graves que, de acordo com os estudos chineses, seriam apenas $20 \%$ dos infectados.

Outro mito que a experiência da Itália desvendou é que o vírus seja perigoso só em idosos. Os virologistas ainda não sabem explicar o porquê e nem tampouco sabem qual seja o discriminante, mas em alguns indivíduos o vírus se manifesta com força e leva à morte muito rapidamente. Claramente, é mais letal em idosos e pessoas com patologias pregressas, porém, até o dia 28 de março, na Lombardia, dos 5914 falecidos, 768 não tinham outras patologias e 194 tinham menos de 65 anos $^{3}$.

O papel da União Europeia e dos aliados históricos da Itália foi deplorável. Se alguns países da Europa deram um mínimo de suporte, recebendo alguns pacientes que necessitavam ser hospitalizados nas UTI, os EUA foram totalmente ausentes. Diversamente, chegaram na Lombardia 53 médicos e enfermeiros cubanos que viabilizaram a abertura de um hospital de campo em Crema, cidade localizada no sul da Região, e uma delegação de médicos chineses, que disponibilizaram todo o know how adquirido na luta contra a epidemia na China. $O$ papel desses últimos, que chegaram no dia 18 de março, foi fundamental para permitir a adoção dos decretos que determinaram medidas mais radicais de combate ao vírus. Quando chegaram, a primeira observação que fizeram foi que, apesar das medidas já tomadas, havia ainda muitas pessoas nas ruas.

61 A União Europeia, além de assumir um papel totalmente marginal na gestão da crise, está sendo o território de uma grotesca batalha entre os países do sul, em particular Itália e Espanha, e os países do norte, Alemanha e Holanda, sobre quais instrumentos econômicos eleger para enfrentar a crise.

O combate à crise do COVID-19 implicará um aumento substancial da dívida pública. Os países europeus já comprometeram recursos significativos para enfrentar a crise, graças à suspensão do Pacto de Estabilidade. Para países como a Itália, que apresentam níveis de dívida muitos altos, pode ser problemática a venda de títulos públicos no 
mercado. O eixo alemão-holandês, portanto, propõe o uso das linhas de crédito do Mecanismo Europeu de Estabilidade (MES), instituído em 2012 para salvar do default Portugal e Irlanda. Trata-se basicamente de um empréstimo a taxa de juros favorável, mas sob condições muito severas. Ao contrário, Itália e Espanha pedem a emissão de Eurobonds, um mecanismo conjunto de distribuição de dívida em nível europeu, através da criação de obrigações de dívida pública dos países pertencentes à zona do euro, a serem emitidas por uma agência específica da União Europeia, cuja solvência é garantida conjuntamente pelos países da União. A expectativa é que o Banco Central Europeu funcione como a Federal Reserve (Fed) nos EUA, cobrindo os spreads e socializando a dívida.

$\mathrm{O}$ aumento exponencial das mortes e as medidas superlimitadoras das liberdades pessoais mexeram muito sobretudo com os italianos das regiões do norte. Muitos perderam amigos e parentes e o que era abstrato e alheio ficou concreto e real como nunca. O choque e a comoção são grandes, quando assistimos inermes as imagens de caminhões do exército cheios de caixões em direção aos crematórios. Assim, doem no coração os contos, tragédia na tragédia, de familiares que perderam suas pessoas queridas deixadas na mais completa solidão na cama de uma UTI, no momento derradeiro do encontro com a morte. Sem o conforto de uma mão ou um olhar amigo nessa desesperada hora. Familiares contam que o seu ente querido foi levado embora pela ambulância e nunca mais o viram, nem mortos, porque os defuntos por COVID-19 são levados às pressas aos crematórios, para evitar ulteriores contágios. Não há possibilidade de um rito fúnebre, sem aquela piedade popular, sem aquele ritual que ajuda a sublimar a perda.

Não é apenas um evento épico, que marca um antes e um depois na história. É também um choque coletivo que afeta nossos corpos. Não seguimos apenas os eventos na tela; sofremos os efeitos todos os dias. O vírus assassino, invisível e incompreensível, que tira o fôlego e causa uma morte horrível, também afeta a vida diária de milhares de maneiras. O pânico inicial, exorcizado nas varandas, foi substituído por um sentimento de tristeza, espanto e resignação amarga. Decreto após decreto, tudo diminuiu, até parar.

Freud, em 1895, define o conceito de trauma como um "corpo estranho" no tecido psíquico e, em 1920, acrescenta que o evento traumático é capaz de provocar uma excitação psíquica que excede a capacidade do sujeito de sustentá-la ou processá-la. Portanto, a essência do trauma é um sentimento de impotência do ego diante de excitações internas ou externas. Um evento traumático consegue abalar a capacidade defensiva do ego. Isso provoca necessariamente medos.

Até agora, os maiores medos dos italianos eram relacionados à suposta "invasão" dos "novos mouros" vindos da África cruzando, com os navios da morte, o Mediterrâneo. Matteo Salvini, nos últimos anos, fomentou os medos soprando sobre a chama da intolerância que, mesmo com níveis diferenciados, arde dentro de cada um de nós. Mas é quando somos coagidos a nos despir de nossas vaidades e vontades que os medos se transformam no que realmente são.

o trauma provocado pelo coronavírus arrasou e banalizou os medos que até então afligiam os italianos, desestabilizando justamente aqueles políticos cuja única razão de existirem é personificar a solução populista vinculando-a aos medos que induzem.

A superação desses medos e dessa intolerância deve ser o primeiro dos legados que essa crise deve escrever no DNA dos italianos. Junto com a necessidade de escolher políticos 
com uma clara visão do futuro, e capazes de enxergar além do horizonte do próprio mandato, tendo como única finalidade o bem comum. A necessidade de reafirmar a centralidade do Estado em alguns setores, como saúde e educação, que não podem se rebaixados a vis mercadorias.

As notícias de golfinhos que estão aparecendo em todos os portos italianos, e dos canais de Veneza com águas limpas e povoados de peixes e aves, devem nos fazer repensar o papel do ser humano no universo e quanto é necessário mudar nosso estilo de vida. Foi suficiente diminuir a presença e a poluição para a natureza retomar os espaços deixados vazios pelos homens. 0 desafio seria garantir uma pacífica convivência baseada sobre o valor universal da saúde, tanto para o homem quanto para a natureza. Bastaria simplesmente diminuir a mobilidade através de formas diferentes de trabalho, como o smart working, para possibilitar de imediato uma diminuição enorme da poluição, do trânsito e do estresse das pessoas, garantido os mesmos níveis de produtividade.

Porém, o legado mais marcante dessa tragédia que nos atingiu será psicológico e, acredito, intimamente interligado com todos aqueles já acima citados. Refiro-me ao imprinting emotivo que influenciará a nossa percepção do futuro. $O$ vírus infectou essa concepção de tempo, tirando a crença no controle total do que virá. E, ao mesmo tempo, nos força a uma nova maneira de envolver o presente, na dimensão incomum e perturbadora da espera.

\section{NOTAS}

1. Fonte: https://www.epicentro.iss.it/

2. Fonte: http://www.salute.gov.it/portale/news/p3_2_1_1_1.jsp? lingua=italiano\&menu=notizie $\& \mathrm{p}=$ dalministero $\& \mathrm{id}=4124$

3. Fonte: ATS Lombardia.

\section{RESUMOS}

Desde o início de 2020, o novo coronavírus aterroriza o mundo inteiro, tendo afetado fortemente a Itália e, mais profundamente, os cidadãos residentes nos territórios pertencentes à Região da Lombardia. A emergência causou grande confusão nos governos, central e regional, que aprovaram uma sucessão de decretos; no campo político, que mudou de ideia várias vezes; e, naturalmente, nos cidadãos. Os especialistas começam a identificar as possíveis causas e deficiências no gerenciamento da crise, mas a maior falha foi a falta de prevenção, envolvendo a ausência de ações dirigidas a equipar hospitais e profissionais de saúde com os meios e as 
ferramentas necessários para enfrentar a crise. No entanto, é mais importante do que nunca saber como transformar experiências negativas em lições valiosas para o futuro.

Da inizio 2020 il nuovo coronavirus terrorizza il mondo intero ed ha colpito fortemente l'Italia e, più profondamente, i cittadini residenti nei territori facenti parte della Regone Lombardia. L'emergenza ha provocato una confusione generalizzata: nei governi, centrale e regionale, che ha approvato un susseguirsi di decreti; in generale nei politici, che hanno più volte radicalmente cambiato idea a riguardo e, naturalmente, nei cittadini. Gli esperti cominciano a individuare le possibili cause e carenze nella gestione della crise, ma la colpa più grande è non aver saputo prevenire, dotando ospedali e operatori sanitari di mezzi e strumenti idenei a fronteggiare la crise. Tuttavia, risulta più che mai importante saper trasformare le esperienze negative in preziose lezioni per il futuro.

Desde principios de 2020, el nuevo coronavirus ha aterrorizado al mundo entero, afectando fuertemente a Italia y, más profundamente, a los ciudadanos que residen en los territorios que pertenecen a la Región de Lombardía. La emergencia causó gran confusión en los gobiernos centrales y regionales, que aprobaron una sucesión de decretos; en el campo político, que cambió de opinión varias veces; $y$, por supuesto, en el ciudadanos. Los expertos están comenzando a identificar las posibles causas y deficiencias en la gestión de crisis, pero el mayor fracaso fue la falta de prevención, que implica la ausencia de acciones destinadas a dotar a los hospitales y profesionales de la salud de los medios y las herramientas necesarias para enfrentar la crisis. Sin embargo, es más importante que nunca saber cómo convertir las experiencias negativas en lecciones valiosas para el futuro.

Right from the beginning of 2020, the new coronavirus has terrorized the entire world, having strongly affected Italy and, more deeply, citizens residing in the territories belonging to the Region of Lombardy. The emergency caused great confusion in the central and regional governments, which approved a succession of decrees; in the political field, which changed its mind several times; and, of course, in citizens. Experts begin to identify possible causes and deficiencies in crisis management, but the biggest flaw was the lack of prevention, involving the absence of actions aimed at equipping hospitals and health professionals with the means and tools necessary to face the crisis. However, it is more important than ever to know how to turn negative experiences into valuable lessons for the future.

Depuis le début de 2020, le nouveau coronavirus terrifie le monde entier, notamment l'Italie et la région de la Lombardie. La Covid-19 a créé une grande confusion parmi les citoyens, les gouvernements centraux et régionaux ont approuvés une succession de décrets et le champ politique a changé d'idée plusieurs fois. Les experts ont commencé à reconnaître les causes et les déficiences par rapport le règlement de la crise. Cependant, la grande faiblesse a été l'absence de la prévention, y compris des outils nécessaires aux hôpitaux et aux professionnels de la santé. Finalement, le plus important c'est savoir comment transformer ces expériences négatives en des conseils précieux vers l'avenir.

\section{ÍNDICE}

Mots-clés: Italie, pandémie, système publique de santé, règlement de la crise, l'avenir.

Keywords: Italy; pandemic; public health system; crisis management; the future

Palabras claves: Italia; pandemia; sistema de salud pública; gestión de crisis; el futuro.

Palavras-chave: Itália; pandemia; sistema público de saúde; gestão de crise; o futuro. 


\section{AUTOR}

\section{ROBERTO MONTEMERLI}

Dottore in Scienze Politiche Università degli Studi di Milano. Serviço de Anagrafe e Estatística Municipal da Prefeitura de Abbiategrasso (Milão) 